Nr 2(65), 2020, s. 143-152

https://doi.org/10.12797/Politeja.17.2020.65.11

\title{
Ewa FIUK
}

Instytut Sztuki Polskiej Akademii Nauk

ewa.fiuk@tlen.pl

\section{DYSKURSY POSTPAMIECCI WE WSPÓŁCZESNYM TRANSNARODOWYM FILMIE NIEMIECKIM}

ABSTRACT Discourses of Post-memory in Contemporary Transnational German Film The article is dedicated to the problem of trauma and death shown in contemporary transnational (made by directors living in Germany, but of non-German origin) German feature, documentary and experimental film. It raises the question of how the medium of film within its various narration and depiction modes (re) creates memory and post-memory, and at the same time it can be seen as a way to reclaim history in its personal or cultural dimension. The following films have been discussed: Totentraum (1995) and In fremder Erde (2001) by Ayhan Salar, Passing Drama (1999) by Angela Melitopoulos and The Cut (2014) by Fatih Akin. For this purpose, the author has implemented inter alia Aleida and Jan Assmann's theory of memory.

Keywords: post-memory, postmigration, genocide, death, trauma

Słowa kluczowe: postpamięć, postmigracje, ludobójstwo, śmierć, trauma 
Groby i wspomnienia nie moga zostać przeniesione ani podbite. [...] Obcy chce i jest w stanie dzielić bezpośrednio z grupa, do której pragnie się zbliżý, w najlepszym razie teraźniejszość i przysztość. Niewatpliwie jednak jest wykluczony z będacych jej udziatem doświadczeń przesztości. Z punktu widzenia grupy, do której pragnie należé, jest on cztowiekiem bez historii ${ }^{1}$.

$\mathrm{T}$ ematem niniejszego artykułu, jak i tematem filmów, o których będzie mowa, jest doświadczenie śmierci rozumianej trojako: jako (traumatyczne) zdarzenie, dzięki któremu uświadamiana jest różnica między przeszłością a teraźniejszością, kontekst międzygeneracyjnego dialogu oraz czynnik konstytuujący tożsamość. Mam na myśli tożsamość żyjących dziś w Niemczech artystów postmigrantów, czyli dzieci robotników zagranicznych, przybyłych do RFN podczas pierwszej fali migracji w latach 1955-1973, urodzonych (lub wychowanych) i wykształconych już tam, reprezentantów niemieckiego kina transnarodowego. Cechą szczególną tego kina jest to, iż współtworzą je właśnie reżyserzy żyjący w Niemczech, lecz posiadający nieniemiecki rodowód, silnie zakorzenieni w tamtejszym porządku społeczno-kulturowym i ekonomicznym, jednocześnie zaś utrzymujący głębokie więzi z kulturą i społeczne relacje z mieszkańcami kraju przodków, co w oczywisty sposób przekłada się na styl i poetykę ich filmów.

Wśród wielu twórców o podobnych biografiach szczególnie interesują mnie ci, którzy poświęcają w swoich filmach uwagę zagadnieniu śmierci i traumy. Należą do nich: Angela Melitopoulos - z pochodzenia Greczynka, urodzona w 1961 roku w Monachium, absolwentka Akademii Sztuk Pięknych w Düsseldorfie; Ayhan Salar - rocznik 1967, Turek, który jako sześciolatek przybył z rodziną do Niemiec, gdzie ukończył filozofię i kulturoznawstwo; oraz Fatih Akın - reżyser urodzony w 1973 roku w rodzinie tureckich migrantów osiadłych w Hamburgu, absolwent tamtejszego wydziału komunikacji wizualnej. Zrealizowane przez nich filmy: Passing Drama (Mijajac Drama), 1999 (reż. A. Melitopoulos), Totentraum (Sen umartego), 1995 i In fremder Erde (Wobcej ziemi), 2001 (reż. A. Salar) oraz Rana (The Cut), 2014 (reż. F. Akın) z uwagi na kraj produkcji są filmami niemieckimi (Rana jest koprodukcją ośmiu krajów, w tym Polski), choć nie podejmują typowo niemieckich wątków. Melitopoulos i Akın odnoszą się do dramatycznych wydarzeń z lat 1914-1924, które miały miejsce na terenie Imperium Osmańskiego, a potem w Turcji - pierwsza opowiada o masowych przesiedleniach i pogromach dokonanych przez Turków na ludności greckiej, drugi o ludobójstwie Ormian. Ayhan Salar zajmuje się kwestią śmierci i pochówku Turków, którzy wiele lat spędzili jako gastarbeiterzy w Niemczech.

A. Schütz, Der Fremde. Ein sozialpsychologischer Versuch, [w:] Transkulturalität. Klassische Texte, red. A. Langenohl, R. Poole, M. Weinberg, Bielefeld 2015, s. 50. Schütz, austriacki Żyd, sam zakosztował goryczy emigranckiego życia, gdy w 1938 roku uciekł przed nazistowskim terrorem z Wiednia najpierw do Paryża, a potem Nowego Jorku. Pierwodruk cytowanego artykułu pochodzi z roku 1944, został więc napisany już na emigracji, opublikowany w „American Journal of Sociology”. O ile nie podano inaczej, tłumaczenia cytatów pochodzą od autorki. 
Dyskurs postpamięciowy widoczny jest szczególnie w przypadku dwóch pierwszych filmów, których twórcy opowiadają o traumatycznych wydarzeniach niebędących ich udziałem, ale przeżytych przez starsze pokolenia. Na tle współczesnego kina niemieckiego, w którym kolektywna pamięć (i postpamięć) pielęgnowana jest głównie w odniesieniu do trzech okresów historycznych - Trzeciej Rzeszy i drugiej wojny światowej, budowy i upadku muru berlińskiego oraz zachodnioniemieckiego terroryzmu lat 70 . i 80. XX wieku - ich filmy należą do wyjątków, jako że wskrzeszają wspomnienia wydarzeń z okresu pierwszej wojny światowej i początku lat 20. ubiegłego wieku. Nie wydaje się jednak, by ich głównym celem było zapisywanie czystych kart historii kina niemieckiego. Sądzę, że horyzont ich artystycznej działalności jest nieco szerszy - twórcom nie chodzi bowiem o sam wkład w rozwój sztuki filmowej, lecz użycie jej do analizy i opisu postmigranckiej kondycji. Odtwarzając bolesną przeszłość narodów, z których się wywodzą, bądź opowiadając o rytuale grzebania zwłok Melitopoulos, Salar i Akın przywołują w swoich filmach kwestię śmierci, by - nawiązując do Schütza - w symboliczny sposób „odzyskać” własną historię.

\section{POSTPAMIĘĆ I FILM}

Przeszłość to konstrukcja spoteczna, ksztaltowana przez potrzebę sensu oraz ramy odniesień dla poszczególnych teraźniejszości. Przesztość nie jest produktem natury, lecz kultury² - powiada Jan Assmann, powołując się na tezy Maurice’a Halbwachsa. Spróbujmy posłużyć się tym cytatem, by jeszcze lepiej wyjaśnić powody powstania filmowych narracji o przeszłości autorstwa Angeli Melitopoulos, Ayhana Salara i Fatiha Akına. Wedle takiego założenia realizacja filmu byłaby dla nich możliwością odnalezienia lub przynajmniej zbliżenia się do sensu traumatycznych przeżyć przodków, sama historia stanowiłaby zaś ramę doniesień dla ich własnej teraźniejszości, kształtowanej w dużym stopniu przez poczucie tożsamości. Przy pomocy filmowych środków wyrazu twórcy ci komunikują swoje wyobrażenia na temat przeszłości (rzeź Greków i Ormian) lub starają się uchwycić moment przejścia teraźniejszości w przeszłość (śmierć i pochówek). Obraz i dźwięk filmowy stają się w ten sposób mediami pamiętania i upamiętniania, które będąc materialnym substratem pamięci, funduja ja, otaczaja $i$ wchodzq w interakcje z pamięciami ludzkimi ${ }^{3}$ - jak pisze Aleida Assmann. Tak jest na poziomie pamięci, w przypadku postpamięci media odgrywają, jak się wydaje, rolę znacznie istotniejszą nie tylko bowiem wchodzą w interakcje z ludzką pamięcią, lecz ją wręcz warunkują.

Omówione poniżej filmy reprezentują rozmaite strategie autorskie i formy filmowej ekspresji - od eksperymentalnego filmu dokumentalnego, zrealizowanego na wzór audiowizualnego eseju (Passing Drama), przez surrealistyczny krótki metraż

J. Assmann, Kultura pamięci, przeł. A. Kryczyńska-Pham, [w:] Pamięć zbiorowa i kulturowa. Wspótczesna perspektywa niemiecka, red. M. Saryusz-Wolska, Kraków 2009, s. 79.

A. Assmann, Przestrzenie pamięci. Formy i przemiany pamięci kulturowej, przeł. P. Przybyła, [w:] Pamięć zbiorowa i kulturowa..., s. 112. 
(Totentraum) oraz tradycyjny pełnometrażowy dokument (In fremder Erde), po należący do nurtu kina popularnego film fabularny stworzony w oparciu o hollywoodzkie wzorce narracyjne (Rana). Zakorzenione w rozmaitych tradycjach filmowych obrazy wpisują się również w różne porządki identyfikacyjne - dotykają kwestii tożsamości społecznej, kulturowej, narodowej, a nawet płciowej, zaś sam dyskurs postpamięciowy odbywa się w nich na dwóch poziomach: diegetycznym, w przypadku którego postmemorialne znaczenia zostają zapośredniczone przez fabułę i bohaterów (Totentraum, In fremder Erde i Rana), oraz formalnym, w którym zapośredniczenie następuje przez formę przedstawienia, zależną od doboru technik audiowizualnych (Passing Drama).

Przyjrzyjmy się teraz fabule i formie wszystkich czterech filmów.

\section{PASSING DRAMA}

Położone w północnej Grecji miasteczko Drama stało się azylem dla wielu Greków, w tym dziadków reżyserki, wypędzonych przez Turków w pierwszej połowie lat 20 . XX wieku z ojczyzny. Niestety dla wielu nie na długo. Ojciec Melitopoulos, podobnie jak setki innych mieszkańców regionu, został w 1942 roku deportowany do Trzeciej Rzeszy, gdzie został robotnikiem przymusowym. Passing Drama jest historią dwóch pokoleń Greków, które spotkała agresja najeźdźców i tragedia wypędzeń oraz wywózek, Greków, którzy pod wpływem traumatycznych doświadczeń niemal do perfekcji opanowali technikę ich wypierania. Reżyserka próbuje je odtworzyć, zarazem jednak przy pomocy środków wizualnych i dźwiękowych stara się oddać ułomność, która stała się udziałem protagonistów, gdy rzeczywisty dramat dobiegł końca - niemożność, nieumiejętność czy też niechęć opowiedzenia o nim.

Passing Drama to zatem z jednej strony film poświęcony konkretnym wydarzeniom i osobom, z drugiej zaś opowieść o samym (nie)pamiętaniu i trudnościach w komunikacji. Filmowa narracja służy upamiętnieniu przeszłości, a jednocześnie obnażeniu mechanizmów i sposobów działania ludzkiej (nie)pamięci. Fabuła i forma filmu oddają wizualnie i audialnie istotę przeżyć protagonistów, które przefiltrowane zostały przez spojrzenie reżyserki - pokoleniowe i artystyczne.

Sposób realizacji filmu jest dla odbiorcy wyzwaniem i zmusza go do aktywnego emocjonalnego i intelektualnego - uczestnictwa. Trudność w odbiorze wynika głównie z narracji, która jest nielinearna i rytmicznie niestabilna. Opowieść w Passing Drama co rusz się urywa, ale ta fragmentaryczność odpowiada niejako niekompletności znamionującej migracyjną (i postmigracyjną) tożsamość protagonistów (i samej reżyserki). Charakterystyczne w Passing Drama są połączenia nie tylko poszczególnych ujęć czy scen, ale także rozmaitych technik i źródeł, zarówno obrazu, jak i dźwięku. W warstwie wizualnej mamy do czynienia z obrazami rejestrowanymi kamerą wideo oraz zdjęciami modyfikowanymi bądź w całości generowanymi w procesie postprodukcji przy pomocy różnych technik wizualizacji. W dość rozbudowanej warstwie audialnej (reżyserka hojnie obdarowuje swój film dźwiękiem, jako że przekazywana ustnie z pokolenia na 
pokolenie historia ucieczek i wywózek konstytuuje się właśnie w tym wymiarze) pojawiają się dźwięki naturalne i nienaturalne, wywiady ze świadkami historii, szumy i inne odgłosy dochodzące zarówno z kadru, jak i spoza niego, nadające filmowi niepokojący, tajemniczy charakter. Powracające motywy wizualne i audialne ustanawiają rytm fabuły, której głównym motywem jest ucieczka. W'śód filmowych środków wyrazu istotną rolę odgrywa w związku z tym montaż, zarówno obrazu z obrazem, dźwięku z dźwiękiem, jak i oczywiście obrazu z dźwiękiem.

Powiedziano, że sposób ustrukturyzowania opowieści, połączenia wątków i materiału jest efektem subiektywnego działania wyobraźni reżyserki, przedstawicielki trzeciego pokolenia, oddającej na ekranie w audiowizualny sposób doświadczenia swoich dziadków i rodziców. Z fragmentów obrazów i dźwięków, a także występujących między nimi luk, widz tworzy całościowy obraz, a więc fabułę, na drodze postrzegania amodalnego, jak w swoim komentarzu do filmu nazywa ten rodzaj percepcji Melitopoulos ${ }^{4}$, która wpisuje swoją opowieść jednocześnie w dwa porządki - publiczny (nawiązując do doświadczenia społeczności wysiedlonych i wywiezionych) oraz prywatny (opowiadając o losach swojej rodziny).

\section{TOTENTRAUM I IN FREMDER ERDE}

W krótkometrażowej, utrzymanej w surrealistycznym tonie fabule pt. Totentraum Ayhan Salar opowiada o migracyjnym losie tureckiej rodziny. Czyni to w sposób dość przewrotny, ponieważ pokazuje nie życie, lecz śmierć, a właściwie przygotowanie do pogrzebu zwłok młodego Turka pracującego jako gastarbeiter w RFN. Eyüp (hebr. Hiob; w islamie imię jednego z proroków) przyjeżdża pewnego dnia pociągiem do Niemiec. Sądząc po szczegółach inscenizacyjnych (zawieszone na fasadzie domu plakaty wyborcze partii SPD widoczne w jednym $\mathrm{z}$ ujęć) akcja filmu rozgrywa się pod koniec lat 60. XX wieku. Widz nie poznaje codziennego życia migranta, ponieważ niemal od razu po scenie ukazującej jego przybycie do RFN ogląda jego zwłoki, które inni Turcy preparują przed złożeniem do trumny. Spoza kadru dobiega głos żony odczytującej list wysłany z Turcji do męża w Niemczech, w którym kobieta prosi go o przysłanie dodatkowych pieniędzy potrzebnych do życia jej i synowi. Oprócz kobiecego głosu w filmie słyszymy dźwięki obmywania zwłok oraz śpiewy muezina. Poszczególne sceny ukazują: żyjącego jeszcze Eyüpa, jego zwłoki (obmywane, zawijane w płótno, a następnie składane do prostej trumny, która zostaje zaniesiona do pociągu jadącego do Turcji) oraz żonę i syna mężczyzny oczekujących jego powrotu do ojczyzny. W ostatniej scenie filmu wysiadający z pociągu na niewielkiej, niemal wyludnionej stacji kolejowej w RFN bohater widzi niesioną do tego samego pociągu trumnę z własnym ciałem.

4 A. Melitopoulos, The materialization of race, 28 II 2008, [online] http://www.darkmatter101.org/ site/2008/02/23/passing-drama-the-materialization-of-race/, 27 X 2019. Amodalny sposób percepcji jest wrodzoną umiejętnością człowieka, który potrafi zrekonstruować w wyobraźni niewidoczne fragmenty przedmiotów. 
Namysł nad śmiercią na obczyźnie Salar kontynuuje w nakręconym sześć lat później pełnometrażowym dokumencie In fremder Erde. Struktura fabularna nakręconego na taśmie $16 \mathrm{~mm}$ filmu opiera się na montażu równoległym umożliwiającym zestawienie dwóch wymiarów grzebania zwłok - duchowego i materialnego, którym odpowiadają dwa wątki narracyjne - opowieść mężczyzny na cmentarzu w Stambule oraz relacja z działalności tureckiej firmy pogrzebowej w Niemczech. Z dokumentu dowiadujemy się, że 99\% Turków zmarłych w Niemczech zostaje przewiezionych po śmierci do kraju przodków, by spocząć na tamtejszych cmentarzach. Na poktadzie każdego samolotu Turkish Airlines, który leci [z Hamburga] do Turcji znajduje się na pewno jedna trumna ze zwtokami ${ }^{5}$ - mówi występująca w filmie Turczynka prowadząca w Hamburgu muzułmański zakład pogrzebowy. Dane te dotyczą początku wieku (film powstał w 2001 roku) i odnoszą się do pierwszej generacji migrantów. Mektube Tasci szacuje jednak, iż przedstawiciele drugiej generacji, a zatem postmigranci, będa już chowani tutaj [w Niemczech]. Ponieważ tu spędzili życie, maja więcej wspólnego z Niemcami niż $z$ Turcja $^{6}$.

Obok informacji na temat formalności, których należy dopełnić w przypadku, gdy chce się wywieźć ciało zmarłej osoby do Turcji bądź pochować muzułmankę czy muzułmanina w Niemczech, obrazu uroczystości pogrzebowych i prezentacji projektu budowy muzułmańskiego cmentarza w rozgrywającej się w Niemczech części filmu zostaje przytoczona niezwykle ciekawa historia dotycząca pewnego berlińskiego cmentarza, który w 1866 roku powstał na ziemi przekazanej Imperium Osmańskiemu przez ówczesnego króla Prus, a potem cesarza Niemiec Wilhelma I, a na którym grzebano posłańców tureckich z uwagi na ograniczone wówczas możliwości transportu zwłok. Jest to najstarszy cmentarz turecki w RFN, który od wielu lat należy do rządu Turcji. Podupadły w okresie drugiej wojny światowej, został odkryty przez migrantów z kraju półksiężyca w latach 60 . i od tamtego czasu jest systematycznie pielęgnowany.

Z filmu Salara dowiadujemy się, że większość napisów na znajdujących się na cmentarzu Şehitlik nagrobkach jest nieczytelna, zaś zarządca cmentarza nie odnawia ich, ponieważ nie wie, jak brzmiały w oryginale. Wiele grobów pozostaje zatem anonimowych, a przynajmniej pozostawało jeszcze na początku wieku, gdy powstał film. Dziś przynajmniej dwie płyty nagrobne zostały odrestaurowane, a umieszczone na nich napisy stały się doskonale widoczne. Odsyłają one do dramatycznych wydarzeń z początku ubiegłego wieku - ludobójstwa dokonanego przez Turków na Ormianach. Chodzi o groby zamordowanych w 1922 roku w stolicy Niemiec organizatorów rzezi Ormian - Cemala Azmiego i Bahaeddina Şakira, którzy w ojczyźnie zostali skazani za swe czyny na karę śmierci, zdążyli jednak zbiec za granicę, zanim ją wykonano. O tych mogiłach, które w ostatnich latach wielokrotnie bywały zarzewiem społeczno-politycznego konfliktu między żyjącymi w RFN Ormianami i Turkami (a także Turkami i Niemcami), ani tym

\footnotetext{
Fragment ścieżki dźwiękowej filmu (wersja dostępna online pod adresem: https://www.youtube.com/ watch?v=Jc-9RnNJLXc, 27 X 2019).
}

6 Tamże. 
bardziej o niechlubnym rozdziale historii Turcji, w filmie Salara nie ma jednak mowy. Nie wiadomo, jaki stosunek do historii kraju przodków ma sam reżyser. Władze Turcji, jak również wiele organizacji tureckich w Niemczech nie uznają zbrodni na Ormianach za ludobójstwo i oskarżają społeczność ormiańską w Berlinie o szerzenie nieprawdy i podżeganie do konfliktów na tle etnicznym7.

\section{RANA}

To, co - świadomie czy też nie - pomija w swoim filmie Salar, jednoznacznie i dobitnie definiuje Fatih Akın w Ranie. Reżyser przez wiele lat był kojarzony z filmami na temat życia migrantów i postmigrantów w RFN, rozdartych między kulturą Zachodu i tradycją Orientu, których losy są w pewnym sensie echem biografii samego twórcy. Akın, który jako jeszcze stosunkowo młody reżyser zdobył dwa z najważniejszych międzynarodowych wyróżnień filmowych - Złotego Niedźwiedzia za film Gtowa w mur (Gegen die Wand) w 2004 roku i nagrodę za scenariusz w Cannes za Na krawędzi nieba (Aufder anderen Seite) w 2007 roku - od dawna marzył o dużej, wysokobudżetowej produkcji w rodzaju kina popularnego. Realizacja filmu na temat ludobójstwa dokonanego przez Turków na Ormianach podczas pierwszej wojny światowej dała mu w końcu taką możliwość. Twórca opowiada w nim o sielskim życiu ormiańskiej rodziny, brutalnie przerwanym przez turecką inwazję. Rodzina wkrótce ulega rozproszeniu - matka zostaje zamordowana, córki wywiezione, a ojciec wysłany wraz z setkami innych mężczyzn w tzw. marszu śmierci na pustynię. Mężczyźnie szczęśliwym trafem udaje się przeżyć piekło wypędzenia i po zakończeniu wojny postanawia odnaleźć swoje córki, w poszukiwaniu których przemierza pół kuli ziemskiej i które w końcu odnajduje w Stanach Zjednoczonych. Autorami scenariusza są Fatih Akın oraz Mardik Martin, amerykański scenarzysta pochodzenia ormiańskiego, który w latach 70. XX wieku współpracował z Martinem Scorsese.

Zrealizowana za ponad 15 milionów euro w stylu amerykańskiego kina popularnego z międzynarodową obsadą i w języku angielskim Rana miała premierę w 2014 roku podczas festiwalu filmowego w Wenecji i otrzymała nawet nominację do Złotego Lwa. Ostatecznie film, oscylujący pomiędzy historycznym zacięciem a sentymentalno-kiczowatym wydźwiękiem kina gatunków, nie zdobył głównego trofeum, a jedynie specjalne wyróżnienie, zaś po wejściu do regularnej dystrybucji został dość chłodno przyjęty zarówno przez krytykę, jak i widzów. Reżyser odpierał potem wysuwane pod jego

Trzeci Turek współodpowiedzialny za zbrodnię ludobójstwa na Ormianach, ważny niegdyś polityk imperium, Talat Paşa, został zamordowany również w Berlinie w 1921 roku i również jego zwłoki pogrzebano na cmentarzu Şehitlik. Dziś jego grób znajduje się Stambule, dokąd został przeniesiony w ramach odświętnej uroczystości przez nazistów w 1943 roku. Zob.: R. Mönch, Wir nennen es Völkermord, „Frankfurter Allgemeine Zeitung” 2015, 20 IV [online], http://www.faz.net/aktuell/ feuilleton/debatten/geschichtsstreit-ueber-armenier-wir-nennen-es-voelkermord-13547073.html?printPagedArticle=true\# pageIndex_2, 19 VIII 2018; M. Leubecher, Ehrengräber für Völkermörder in Berliner Moschee, „Die Welt” 2015, 20 IV, [online] https://www.welt.de/politik/deutschland/article139816650/Ehrengraeber-fuer-Voelkermoerder-in-Berliner-Moschee.html, 27 X 2019. 
adresem zarzuty, mówiąc, że Rana powstała przede wszystkim z pobudek osobistych oraz w celu uczczenia pamięci pomordowanych Ormian, nie zaś po to, by zrewolucjonizować sztukę filmową. Otwarcie mówił również o nadziejach, jakie pokłada w filmie w związku z jego recepcją w Turcji ${ }^{8}$ I rzeczywiście tamtejsze opinie były wyważone i stosunkowo przychylne, widownia umiarkowanie liczebna, a komentarze krytyków pozbawione argumentów emocjonalnych. Wbrew wcześniejszym zapowiedziom tureckich nacjonalistów w kraju przodków Akına obyło się także bez skandalu, choć jeszcze przed premierą niektórzy wzywali do bojkotu filmu, a w sieci pojawiły się śmiertelne pogróżki skierowane do twórcy. Kara za kalanie własnego gniazda spadła na „winowajcę" paradoksalnie w Niemczech - podobno niektórzy jego tureccy znajomi z Hamburga zerwali z nim kontakt. Sam twórca komentuje położenie, w jakim się znalazł, tak: Byćmoże powinien byt się za to wziaćniemiecki Turek, który w Niemczech nauczyt się, jak obchodzićsię z mrocznymi rozdziatami historii, by pomóc Turkom i Ormianom przezwyciężý ich traumę. [...] To jest film dla szerokiej publiczności, zostat zrealizowany tak, by pokazato go kilka duzych kin $w$ Turcji. Jeśli to siępowiedzie, nasza zastuga nie będzie może to, że turecki rzad uzna ludobójstwo, ale to, że zacznie się o nim mówiç.

Rana to film, który dla jednych jest wyrazem szacunku i poczucia sprawiedliwości względem ofiar jednej z największych zbrodni przeciwko ludzkości, wyczekiwanym głosem w dyskusji na temat winy Turków za śmierć milionów niewinnych, dla drugich zaś afrontem, a w najlepszym wypadku niesmacznym gestem rozkapryszonego artysty, reprezentanta zgniłego Zachodu, którego należy ukarać społecznym ostracyzmem. Jakkolwiek byśmy go odbierali, film Fatiha Akına łamie tabu i przywraca pamięci wypierany nadal przez wielu fragment historii. Reżyser opowiada o traumie ofiar, w pośredni sposób dotykając także traumy sprawców, narodu, z którego sam się wywodzi i którego historię, nawet tę najmroczniejszą, chce odkryć, także po to, by poznać genezę części własnej tożsamości.

Śmierć, która w różnym stopniu stanowi temat wszystkich omówionych powyżej filmów, jest bardzo istotnym doświadczeniem w porządku pamięci i postpamięci. [...] jeśli kultura pamięci [i postpamięci] jest przede wszystkim odniesieniem do przesztości, przesztość zaś powstaje, kiedy uświadamiamy sobie różnice między wczoraj a dziś, to najbardziej pierwotne doświadczenie tej różnicy stanowi śmiercic $c^{10}$ - pisze Jan Assmann. Owo „dziš" niemieckich reżyserów, autorów kina o transnarodowym charakterze, których reprezentują tu Melitopoulos, Salar i Akın, jest przestrzenią kształtowania tożsamości, szczególną, gdyż konstytuującą się w warunkach postmigracji.

8 J. Dettke, Der Skandal ist ein Märchen, „Die Zeit” 2014, 1 IX, [online] https://www.zeit.de/kultur/ film/2014-09/fatih-akin-the-cut-venedig, 27 X 2019.

9 P. Bauer, Wie im falschen Film, „Süddeutsche Zeitung Magazin” 2014, 8 X, [online] https://sz-magazin.sueddeutsche.de/film-und-kino/wie-im-falschen-film-80695, 27 X 2018.

10 J. Assmann, Kultura pamięci..., s. 93-94. 
Twórcy wspominają traumę, a wraz z nią (swoich) zmarłych, gdyż proces ten stanowi, jak twierdzi Assmann, najbardziej pierwotna formę kultury pamięci [i postpamięci] ${ }^{11}$. Czynią to jednak właśnie także dlatego, że wspominanie zmartych jest w paradygmatyczny sposób pamięcią, która tworzy wspólnotę. Przez więź ze zmartymi zbiorowość potwierdza swoją tożsamośćc ${ }^{12}$.

To właśnie między innymi (post)pamięć o śmierci, o człowieku po śmierci i miejscu jego pochówku pozwala (post)migrantowi, Obcemu „odzyskać” własną historię. Nawet jeśli pozostaje on wykluczony $z$ będących jej [grupy, do której chciałby należeć] udziatem doświadczeń przesztości, by posłużyć się terminologią z cytatu umieszczonego na początku artykułu, nie jest już „cztowiekiem bez historii”. Dowodzą tego postpamięciowe narracje Melitopoulos, Salara i Akına, które w twórczy sposób rozwijają wiekową i śmiałą tezę Alfreda Schütza. Pomysł na film i możliwość jego produkcji, krótko: akt twórczy, jest tu elementem kluczowym, gdyż uświadamia nie tylko potrzebę przekroczenia - czy może lepiej upłynnienia - granicy między grupą a jednostką spoza niej, ale także potencjał tkwiący w tym działaniu, który sprawia, że to, co dla austriackiego socjologa w latach 40. ubiegłego wieku było niewyobrażalne, dziś jest nie tylko możliwe, ale i praktykowane.

\section{BIBLIOGRAFIA}

Assmann A., Przestrzenie pamięci. Formy i przemiany pamięci kulturowej, przeł. P. Przybyła, [w:] Pamięć zbiorowa i kulturowa. Wspótczesna perspektywa niemiecka, red. M. Saryusz-Wolska, Kraków 2009.

Assmann J., Kultura pamięci, przet. A. Kryczyńska-Pham, [w:] Pamięć zbiorowa i kulturowa. Wspótczesna perspektywa niemiecka, red. M. Saryusz-Wolska, Kraków 2009.

Bauer P., Wie im falschen Film, „Süddeutsche Zeitung Magazin” 2014, 8 X, [online] https://sz-magazin.sueddeutsche.de/film-und-kino/wie-im-falschen-film-80695, 27 X 2019.

Dettke J., Der Skandal ist ein Märchen, „Die Zeit” 2014, 1 IX, [online] https://www.zeit.de/ kultur/film/2014-09/fatih-akin-the-cut-venedig, 27 X 2019.

Leubecher M., Ehrengräber für Völkermörder in Berliner Moschee, „Die Welt” 2015, 20 IV, [online] https://www.welt.de/politik/deutschland/article139816650/Ehrengraeber-fuerVoelkermoerder-in-Berliner-Moschee.html, 27 X 2019.

Melitopoulos A., The materialization of race, 28 II 2008, [online] http://www.darkmatter101. org/site/2008/02/23/passing-drama-the-materialization-of-race/, 27 X 2019.

Mönch R., Wir nennen es Völkermord, „Frankfurter Allgemeine Zeitung” 2015, 20 IV, [online] http://www.faz.net/aktuell/feuilleton/debatten/geschichtsstreit-ueber-armenier-wirnennen-es-voelkermord13547073.html?printPagedArticle=true\#pageIndex_2, 27 X 2019.

Schütz A., Der Fremde. Ein sozialpsychologischer Versuch, [w:] Transkulturalität. Klassische Te$x t e$, red. A. Langenohl, R. Poole, M. Weinberg, Bielefeld 2015.

11 Tamże, s. 94.

12 Tamże, s. 96. 
Dr Ewa FIUK - filmoznawczyni, adiunktka w Instytucie Sztuki Polskiej Akademii Nauk. Autorka monografii Inicjacje, tożsamość, pamięć. Kino niemieckie na przetomie wieków i Obrazo-światy, dźwięko-przestrzenie. Kino Toma Tykwera oraz wielu publikacji, w tym także przekładów z języka niemieckiego, w tomach zbiorowych i czasopismach. Redaktorka „Kwartalnika Filmowego”. Zainteresowania naukowe: film niemiecki, transkulturowość, teoria afektu i narracje mniejszościowe (ze szczególnym uwzględnieniem migracji) w kontekście twórczości filmowej. 